\title{
Are boys better than girls at building a tower or a bridge at 2 years of age?
}

Clinique du Tertre Rouge, Department of Neonatology,

Le Mans 72100, France

Correspondence to: Dr J C Labarthe,

4 place Adrien Tironneau, Le Mans, 72100 France.

Accepted 23 April 1997

Jean Christophe Labarthe

\begin{abstract}
This study was designed to look at the differences in visuospatial abilities between boys and girls before they can speak fluently. At the mandatory two year follow up visit, children were given the opportunity to build a tower and a bridge. In children whose birth weight was $\geqslant 2500$ $\mathrm{g}$, the capacity for erecting a tower was the same in both sexes, but for building a bridge striking differences were noted according to their sex. Among the 376 children of this category, 41 out of 199 boys (21\%) were able to build a bridge in comparison with 15 out of 177 girls (8\%). This difference is highly significant. In children whose birth weight was $\leqslant 2500 \mathrm{~g}$, no differences were noted either for building a tower or a bridge. By showing that boys outnumber girls among the most skilled toddlers in spatial abilities, this work confirmed the action of a male related factor on cerebral lateralisation.

(Arch Dis Child 1997;77:140-144)
\end{abstract}

Keywords: spatial cognition; cerebral lateralisation; gifted children

One of the most fascinating aspects of the follow up of a child is the check up of developmental milestones from birth to school age. To fully appreciate such an area, paediatricians must feel at ease with the functioning of the human brain, which seemed simple to understand according to the hypotheses of Broca in the previous century, but which now is regarded as highly intricate.

Fortunately, the articles written by Geschwind and Galaburda about cerebral lateralisation provided a new insight. ${ }^{1-3}$ On the basis of a huge list of experimental, anatomical, and clinical studies in animals and humans, 10 years ago they rejuvenated the exciting theory of cerebral lateralisation. Their main conclusions may be described as follows: (1) the left hemisphere matures later than the right. (2) A delay in development of some cortical regions on the left side should favour growth of cortical regions on the opposite side, and in unaffected regions of the same side. This is a hypothesis which would explain the asymmetry in the human brain that was observed in 1968 by Geschwind and Levitsky. ${ }^{4}$ (3) The left hemisphere is usually dominant for language and manual skills while the right is more involved in certain spatial and musical abilities, attention, and many aspects of emotion.
The most striking idea put forward by the two authors is that the difference in the human brain between men and women is linked to a male related factor which may be outside of the gene pool, and whose main effect leads to a slowing down of the development of the left hemisphere. In other words, we can say that according to Geschwind and Galaburda, growth retardation will generally be more marked in certain left hemisphere regions in men, who will therefore show, on average, a greater degree of shift to right hemisphere participation in handedness and language and will therefore be more likely to have augmented right hemisphere skills.

A set of studies, quoted by Geschwind and Galaburda, seems to back up their theory because these works have shown the superiority of men in spatial talents. ${ }^{2}$ These studies have, however, evaluated humans a long time after they had reached their full ability in the use of language, and therefore they were not able to rule out the possible influence of language on the expression of spatial skills. On the other hand, 2 year old children should be very good subjects for the study of the functioning of the right side of the brain because they are able to build some objects, and the majority do not speak at all. In France, general practitioners, particularly paediatricians, have the opportunity to examine children on their second birthday, because a 'well child' visit is mandatory and results in the doctor writing out a medical certificate, which is necessary for parents to get child allowance.

The purpose of this present study was to determine whether boys are better than girls at using visuospatial abilities by investigating in 2 year old children, according to their sex, the ability to build a bridge, which is a very difficult task at this age.

\section{Subjects and methods}

SUBJECTS

Children were enrolled from my private surgery between December 1991 and December 1994. Eligible subjects were those between 23 and 25 months of age, and in good health without acute illness at the time of my medical survey. Exclusion criteria included (a) multiple congenital anomalies, (b) cerebral malformations, (c) cerebral palsy, (d) offspring of drug abusing mother, (e) genetic diseases impairing the brain's functioning such as Down's syndrome. After a preliminary study I planned to enrol about 500 children equally divided into boys and girls. This sample size was chosen to observe a statistically significant difference 
$(\mathrm{p}<0.05)$ if the chance of success at the bridge test was $15 \%$ for boys and only $7 \%$ for girls.

During this three year period, I evaluated 248 boys and 230 girls, of whom 23 boys and 24 girls showed a great reluctance to do the bridge test, and thus were excluded from the study leaving 225 boys and 206 girls to be checked. The reluctant children were not significantly different from the willing ones with respect to weight, height, and head circumference at 2 years of age and at birth. Furthermore, in order to rule out the deleterious impact of prematurity on the brain's performances, the children were stratified on the basis of their birth weight, that is $<$ or $\geqslant$ $2500 \mathrm{~g}$ and this study particularly focused on children $\geqslant 2500 \mathrm{~g}$. Birth weight was chosen as a means to assess prematurity because gestational age was not reliably shown in the medical file. The possible inclusion of premature infants in the cohort of children $\geqslant 2500 \mathrm{~g}$ was regarded as a trivial bias, anyway, because in evaluating developmental milestones, correction for prematurity is no longer necessary in the second year of life according to Ouden et $a .^{5}$

TESTING PROCEDURES

After a thorough physical examination, children were asked to sit down before my desk on their mother's knees in order to calm them down as much as possible.

Children were given some wooden blocks whose sides were $3.3 \mathrm{~cm}$ in length, and were asked to build a tower as high as possible, after having seen how I managed to put one block on top of the other. To count the number of blocks making up a tower I did not take into account the block which caused the tower's fall when it was placed on top.

The wooden blocks used for the bridge's pillars had sides of $2.4 \mathrm{~cm}$. The brick used for the bridge's roof had dimensions $4.9 \mathrm{~cm}, 2.4 \mathrm{~cm}$, and $1.1 \mathrm{~cm}$ in length, width, and thickness, respectively. To make it easier for the children to remember, I chose one colour for the pillars and another one for the roof. Before asking children to make a bridge, I showed them the different steps necessary to build the bridge, emphasising the correct distance between the pillars, which was large enough to allow a finger to slide under the bridge but small enough to hold up the bridge's roof. If a child failed at the first attempt, I explained the process again. The child was then allowed one more try.

Three groups of children for each sex were set up according to their result at the bridge test-group 1: failure group, including those who failed, and built a tower with the three blocks rather than a bridge, or those who put the pillars on the roof as a reverse bridge; group 2: semisuccess group, including those who were on the right track to building the bridge, that is, those who were able to set down the roof on the pillars but were not able to move the pillars away from each other to make a gap under the roof; and group 3: full success group, including those who succeeded in building the bridge in whatever way they chose to make it; either they made it in the same way as those in

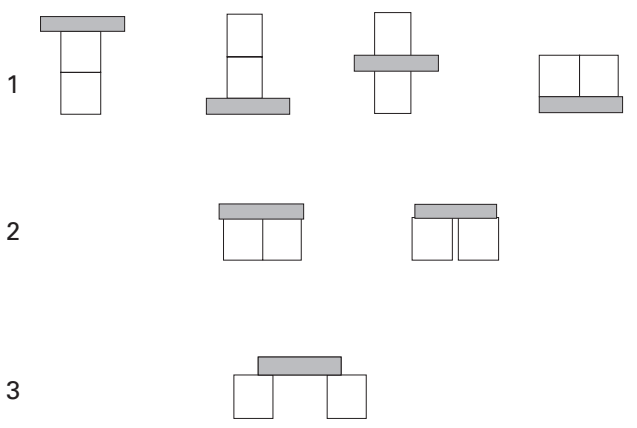

Figure 1 The different ways of building a bridge: 1 failure group, 2 semisuccess group, 3 full success group.

group 2 but they succeeded in making a gap under the roof, or they moved the pillars apart from each other as their first step and then put down the roof on the pillars. This last way was the one I taught the children (see fig 1).

\section{STATISTICAL ANALYSIS}

Likelihood of full success at the bridge test compared with semisuccess and failure according to the sex of children was estimated by computation of the odds ratios and their 95\% confidence intervals (CI). Odds ratios were considered significant when 1.0 was not included in the $95 \%$ CI. The differences among the three groups of children of the same sex with respect to physical variables were compared using analysis of variance, and the Student's $t$ test. The same method was chosen to determine the differences, among children of the same sex sorted out according to their group, between the means of the number of blocks making up a tower in crude number and after logarithmic transformation to fulfil the assumption of the normal distribution of this particular continuous variable. A p value less than 0.05 on any statistical test was regarded as significant.

\section{Results}

CHILDREN WITH BIRTH WEIGHT $\geqslant 2500 \mathrm{G}$ Among the 199 boys whose birth weight was $\geqslant 2500 \mathrm{~g}, 106(53 \%)$ were in group 1,52 $(26 \%)$ in group 2 , and $41(21 \%)$ in group 3. Among the 177 corresponding girls, 113 $(64 \%)$ were in group $1,49(28 \%)$ in group 2 , and only $15(8 \%)$ in group 3. In other words, in children whose birth weight was $\geqslant 2500 \mathrm{~g}$ and who were consequently considered as term or near term infants, $21 \%$ of boys compared with $8 \%$ of girls were able to build a bridge at the age of 2 years. This difference is highly significant giving an odds ratio with $95 \%$ CI of 2.8 (1.49 to 5.27 )

Table 1 shows morphometric data of boys characterised by a birth weight $\geqslant 2500 \mathrm{~g}$, and by their result at the bridge test. At birth these data were not significantly different among the three groups. At the age of 2 years, mean head circumference was significantly higher in boys of group 3 than that in boys of group 1: 49.8 (1.2) $\mathrm{cm} v 49.2(1.3) \mathrm{cm}$, mean (SD), $\mathrm{p}<0.02$. Weight and height were of similar value among the boys of the three groups.

Table 2 illustrates morphometric data in girls with birth weight $\geqslant 2500 \mathrm{~g}$, and stratified also 
Table 1 Morphological data of the three groups of boys with birth weight $\geqslant 2500 \mathrm{~g}$; values are mean (SD)

\begin{tabular}{|c|c|c|c|c|c|c|}
\hline & Group 1 & $\begin{array}{l}\text { No of } \\
\text { boys }\end{array}$ & Group 2 & $\begin{array}{l}\text { No of } \\
\text { boys }\end{array}$ & Group 3 & $\begin{array}{l}\text { No of } \\
\text { boys }\end{array}$ \\
\hline \multicolumn{7}{|l|}{ At birth } \\
\hline Weight (g) & $3320 \quad(440)$ & 106 & $3390 \quad(370)$ & 52 & $3410 \quad(420)$ & 41 \\
\hline Length $(\mathrm{cm})$ & $50.1(2.0)$ & 106 & $50.3(1.9)$ & 52 & $50.6(1.9)$ & 40 \\
\hline Head circumference $(\mathrm{cm})$ & $34.8(1.3)$ & 102 & $34.7(1.3)$ & 50 & $35.1(1.1)$ & 40 \\
\hline \multicolumn{7}{|l|}{ At 2 years } \\
\hline Weight (kg) & $12.3(1.4)$ & 106 & $12.4(1.2)$ & 52 & $12.7(1.3)$ & 41 \\
\hline Height $(\mathrm{cm})$ & $86.8(3.0)$ & 106 & $87.5(3.0)$ & 52 & $87.6(2.5)$ & 41 \\
\hline Head circumference $(\mathrm{cm})$ & $49.2(1.3)$ & 104 & $49.5(1.0)$ & 52 & $49.8(1.2)$ & $40^{\star}$ \\
\hline
\end{tabular}

Table 2 Morphological data of the three groups of girls with birth weight $\geqslant 2500 \mathrm{~g}$; values are mean (SD)

\begin{tabular}{|c|c|c|c|c|c|c|}
\hline & Group 1 & $\begin{array}{l}\text { No of } \\
\text { girls }\end{array}$ & Group 2 & $\begin{array}{l}\text { No of } \\
\text { girls }\end{array}$ & Group 3 & $\begin{array}{l}\text { No of } \\
\text { girls }\end{array}$ \\
\hline \multicolumn{7}{|l|}{ At birth } \\
\hline Weight (g) & 3220 & 113 & $3290 \quad(290)$ & 49 & $3300 \quad(330)$ & 15 \\
\hline Length $(\mathrm{cm})$ & $49.5(1.9)$ & 111 & $49.6(1.6)$ & 48 & $49.5(2.0)$ & 15 \\
\hline Head circumference $(\mathrm{cm})$ & $34.1(1.2)$ & 110 & $34.3(1.1)$ & 47 & $34.3(1.0)$ & 15 \\
\hline \multicolumn{7}{|l|}{ At 2 years } \\
\hline Weight $(\mathrm{kg})$ & $12.0(1.4)$ & 113 & $12.2(1.3)$ & 49 & $11.7(1.2)$ & 15 \\
\hline Height $(\mathrm{cm})$ & $86.2(2.8)$ & 113 & $86.3(2.5)$ & 49 & $85.6(3.5)$ & 15 \\
\hline Head circumference $(\mathrm{cm})$ & $48.1(1.2)$ & 113 & $48.2(1.1)$ & 48 & $48.3(1.3)$ & 15 \\
\hline
\end{tabular}

Table 3 Number of blocks used in towers built by the three groups of 2 year old children whose birth weight was $\geqslant 2500 \mathrm{~g}$; values are mean (SD)

\begin{tabular}{lllllll}
\hline & Group 1 & $\begin{array}{l}\text { No of } \\
\text { children }\end{array}$ & Group 2 & $\begin{array}{l}\text { Noof } \\
\text { children }\end{array}$ & Group 3 & $\begin{array}{l}\text { No of } \\
\text { children }\end{array}$ \\
\hline Boys & $6.4(2.5)$ & 106 & $7.5(2.7)$ & 49 & $8.3(2.9)$ & $40^{\star}$ \\
Girls & $6.6(2.6)$ & 110 & $7.2(2.3)$ & 45 & $8.7(2.8)$ & $15 \dagger$
\end{tabular}

${ }^{\star} \mathrm{p}<0.001$ (group $3 v$ group 1 ) $; \dagger \mathrm{p}<0.01$ (group $3 v$ group 1 ).

Table 4 Morphological data in boys with birth weight $<2500$ g; values are mean (SD)

\begin{tabular}{|c|c|c|c|c|c|c|}
\hline & Group 1 & $\begin{array}{l}\text { No of } \\
\text { boys }\end{array}$ & Group 2 & $\begin{array}{l}\text { No of } \\
\text { boys }\end{array}$ & Group 3 & $\begin{array}{l}\text { No of } \\
\text { boys }\end{array}$ \\
\hline \multicolumn{7}{|l|}{ At birth } \\
\hline Weight (g) & $1990 \quad(400)$ & 18 & $2100 \quad(390)$ & 6 & $2320 \quad(-)$ & 2 \\
\hline Length $(\mathrm{cm})$ & $44.6(2.9)$ & 17 & $44.7(3.1)$ & 6 & $48.0(-)$ & 2 \\
\hline Head circumference $(\mathrm{cm})$ & $30.7(1.6)$ & 17 & $32.4(2.0)$ & 6 & $31.5(-)$ & 2 \\
\hline \multicolumn{7}{|l|}{ At 2 years } \\
\hline Weight $(\mathrm{kg})$ & $11.5(1.3)$ & 18 & $12.0(0.4)$ & 6 & $10.9(-)$ & 2 \\
\hline Height $(\mathrm{cm})$ & $84.9(3.5)$ & 18 & $86.2(2.4)$ & 6 & $85.6(-)$ & 2 \\
\hline Head circumference $(\mathrm{cm})$ & $48.0(1.8)$ & 18 & $49.2(1.9)$ & 6 & $49.2(-)$ & 2 \\
\hline
\end{tabular}

Table 5 Morphological data in girls with birth weight < $2500 \mathrm{~g}$; values are mean (SD)

\begin{tabular}{lccccccc}
\hline & Group 1 & $\begin{array}{l}\text { No of } \\
\text { girls }\end{array}$ & Group 2 & $\begin{array}{l}\text { No of } \\
\text { girls }\end{array}$ & Group 3 & $\begin{array}{l}\text { No of } \\
\text { girls }\end{array}$ \\
\hline At birth & & & & & & & \\
$\quad$ Weight (g) & $2040 \quad(390)$ & 21 & $2090 \quad(430)$ & 6 & 2220 & $(-)$ & 2 \\
$\quad$ Length (cm) & $44.4(2.6)$ & 21 & $44.4(2.5)$ & 5 & $46.0(-)$ & 2 \\
$\quad$ Head circumference (cm) & $31.0(1.5)$ & 21 & $30.8(2.8)$ & 5 & $31.5(-)$ & 2 \\
At 2 years & & & & & & \\
$\quad$ Weight (kg) & $10.7(1.0)$ & 21 & $10.8(1.0)$ & 6 & $11.1(-)$ & 2 \\
$\quad$ Height (cm) & $83.5(3.0)$ & 21 & $84.4(2.1)$ & 6 & $85.0(-)$ & 2 \\
Head circumference (cm) & $47.3(1.9)$ & 21 & $47.0(1.0)$ & 6 & $47.3(-)$ & 2 \\
\hline
\end{tabular}

by their result at the bridge test. No statistically significant differences were found among the girls in the three groups with respect to weight, height, and head circumference either at birth, or at the age of 2 years.

The size of the tower made by boys with birth weight $\geqslant 2500 \mathrm{~g}$, and belonging to group 3 (the full success group at the bridge test), was significantly greater than that raised by boys from group 1 (failure group at the bridge test): mean (SD) 8.3 (2.9) v 6.4 (2.5) blocks, $\mathrm{p}<0.001$ (see table 3). The same scheme was observed for the girls whose birth weight was $\geqslant 2500$ g: 8.7 (2.8) $v 6.6$ (2.6) blocks, $\mathrm{p}<0.01$ for groups 3 and 1 respectively (see table 3 ). After logarithmic transformation of the number of blocks, these statistically significant differences among boys and girls of groups 1 and 3 were found again (data not shown).

There were no significant differences in the means of the number of blocks making up a tower between boys and girls belonging to the same group defined by the result at the bridge test (see table 3).

CHILDREN WITH BIRTH WEIGHT $<2500 \mathrm{G}$

Tables 4 and 5 show physical data of boys and girls whose birth weight was $<2500 \mathrm{~g}$, and grouped by their result at the bridge test made at the age of 2 years. Among the 26 boys there were two whose birth weight was between 1000 and $1499 \mathrm{~g}$, seven between 1500 and $1999 \mathrm{~g}$, and 17 between 2000 and $2499 \mathrm{~g}$. Among the 29 girls there were four whose birth weight was between 1000 and $1499 \mathrm{~g}$, six between 1500 and $1999 \mathrm{~g}$, and 19 between 2000 and $2499 \mathrm{~g}$.

To compare children from the three groups, statistical analyses were not carried out because gestational ages were not precisely known, making interpretation of any observed difference unsatisfactory.

Two boys $(7.7 \%)$ and two girls $(6.9 \%)$ were able to build a bridge very well, thus belonging to group 1 . Their birth weights were just below $2500 \mathrm{~g}$, from 2150 to $2450 \mathrm{~g}$.

The results of the tower test in group 1 children of both sexes with birth weight $<2500 \mathrm{~g}$ were similar to those of their counterparts with birth weight $\geqslant 2500 \mathrm{~g}$ (see tables 3 and 6 ). The number of children of both group 2 or 3 was too small to make statistical comparisons with their peers whose birth weight was $\geqslant 2500 \mathrm{~g}$ (see table 6).

\section{Discussion}

The most striking result of this study is that boys are more than twice as likely than girls to build a bridge from memory at the age of 2 years.

This task was very hard to fulfil with a success rate of $8 \%$ in girls and $21 \%$ in boys, for children whose birth weight was $\geqslant 2500 \mathrm{~g}$. It does not need language skills, but spatial abilities. In other words this study showed that among the most gifted 2 year old children in spatial functions, boys in comparison with girls were overrepresented. But for children whose birth weight was $<2500 \mathrm{~g}$, it was not possible to detect such a difference between the two sexes.

The superiority of boys over girls at the bridge test in the top group of children is in agreement with the hypothesis about sex hormone influences on brain growth supported by Geschwind and Galaburda. ${ }^{1-3}$ They proposed that the slower development of the left brain is caused by a male related factor which must be outside of the fetal gene pool, the only condition which could account for similar, although less marked, effects in the female fetus. Through results from experiments in rats they thought this male related factor was likely 
Table 6 Number of blocks used in towers built by the three groups of 2 year old children whose birth weight was < $2500 \mathrm{~g}$; values are mean (SD)

\begin{tabular}{lllllll}
\hline & Group 1 & $\begin{array}{l}\text { No of } \\
\text { children }\end{array}$ & Group 2 & $\begin{array}{l}\text { Noof } \\
\text { children }\end{array}$ & Group 3 & $\begin{array}{l}\text { No of } \\
\text { children }\end{array}$ \\
\hline Boys & $6.6(2.0)$ & 18 & $4.2(1.5)$ & 5 & ND $^{\star}$ & 2 \\
Girls & $5.9(2.5)$ & 20 & $5.5(1.6)$ & 6 & $10.0(-)$ & 2 \\
\hline
\end{tabular}

${ }^{\star} \mathrm{ND}=$ not done because of reluctance to do the test.

to be testosterone. The effect of testosterone, as has been known for a long time, may depend either on the level of free hormone or on tissue sensitivity. Some female fetuses in whom sensitivity is high are thus likely to show excessive testosterone effects. The growth retardation in certain left hemisphere regions, which is more marked in boys than in girls, will lead, according to both authors, to a compensatory growth of the homologous areas of the opposite hemisphere and the adjacent regions in the same hemisphere. The higher the compensatory growth, the greater the skills emerging from these areas are expected to be. In other words, boys who may have a greater compensatory growth in the right side of the brain than girls, the side of most spatial functions, and which is in fact responsible for prelinguistic learning, ${ }^{6}$ are likely to show higher talents in spatial abilities than girls. The fact that the left hemisphere has recently been considered to control some spatial skills, such as mental rotation, does not detract from the theory about the leading role of male sex hormone on brains in humans. ${ }^{78} \mathrm{It}$ is enough to keep in mind that the compensatory growth affects both hemispheres.

The finding that boys outnumber girls among highly talented 2 year old children in spatial ability is in keeping with the results of the meta-analysis carried out by Hedges and Nowell. ${ }^{9}$ Spatial ability was assessed in only two of the six studies making up their metaanalysis, the first in 1960 looked at a set of 73425 teenagers, all 15 years of age, the second in 1980 evaluated 25069 12th grade students. In these two huge studies, boys outnumbered girls among children who scored in the top 5\% nationally in spatial function. The ratios of the number of boys to the number of girls belonging to this top $5 \%$ were 2.33 and 2.39 for these two studies respectively. In my work, the ratio of the number of boys who were able to build a bridge and whose birth weight was $\geqslant 2500 \mathrm{~g}$ to the number of girls of the same class was 2.73 , and these toddlers constituted about $15 \%$ of the whole sample of children belonging to the same class of birth weight.

The fact that children at the age of 2 years may be assessed for spatial functions by a tool as simple and powerful as the bridge test should be highlighted. On the other hand, although the tower test showed a significant difference in the number of blocks used to make a tower between children belonging to group 1 and group 3, this test turned out not to be as efficient as the bridge test in identifying the most skilled children in spatial area. This was because a lot of children who could build a tower very well, could not complete the bridge test (data not shown).
This study has three main shortcomings which need to be overcome before these new findings in toddlers could be confirmed in older children. Firstly, laterality was not assessed in the 2 year old children, because I did not think it was possible to get a precise idea of lateral preference at this age. Consequently, I was not able to document a relation between superior right hemisphere functions and left handedness in both sexes, a relation which is one of the cornerstones of Geschwind and Galaburda's theory. Secondly, the bridge test as defined in this study requires two cerebral functions, short term memory and spatial reasoning ability. We can imagine that the better performance of boys at this task compared with that of girls would be the result of a more efficient short term memory only and not better spatial capacity. Every child, however, had two attempts at building a bridge, thus ruling out the possibility that short term memory was the main determinant in the ability to do the test. Unfortunately, I did not make a note of the children who were able to build a bridge at the first try. Moreover, in three of the tests used by Hedges and Nowell, the children were given a picture number task, which is a test of associative memory, and they found that, on average, girls tended to perform better than boys in this cerebral area. ${ }^{9}$ Thirdly, the impact of possible training on the children's results at the bridge test is a very difficult question to answer. In order to avoid this pitfall I prepared parents for this examination of their 2 year old child by asking them to train their child to speak, draw, and to build a tower with blocks, but I deliberately hid from them my own interest in the bridge test. In fact this strategy could not preclude any discussion among sets of parents about the bridge test after the visit, and consequently a more specific training for some children. On the other hand, my request that children be trained before the 2 year visit must have erased the possible preference for playing with blocks between boys and girls. Moreover the fact that girls are as clever as boys at building a tower rules out the possibility of a lack of training for girls.

Another interesting finding in this study is that the most skilled boys at the bridge test had a statistically significant greater head circumference at the age of 2 years than the less skilled ones. Recently Willerman et al reported a relation between brain size and intelligence, and suggested that in normal adults the differences in brain size help to explain differences in intelligence test performance. ${ }^{10}$ This relation was also found out by Sells et al in infants of diabetic mothers and their control counterparts. ${ }^{11}$ In their study, head circumference at 2 and 3 years of age correlated significantly with the three year Standford-Binet IQ test in infants of diabetic mothers, while head circumference in control infants correlated with the three year Standford-Binet IQ test only at 6 months of age but did not at the age of 2 or 3 years.

In conclusion, by showing that boys outnumber girls among the most skilled toddlers in spatial abilities, this work seems to confirm the 
role of a male related factor in the development of prelinguistic learning. Whether or not the theory of cerebral lateralisation may lead to a change of the syllabus used to teach children before they learn to read is debatable and needs to be studied further before a conclusion can be reached. The way to increase specific talents in children according to their sex, that is, spatial abilities in boys and linguistic capacities in girls, should also be examined in the future.

I am grateful to Peter A Blasco for reviewing this manuscript.

1 Geschwind N, Galaburda AM. Cerebral lateralization: biological mechanisms, associations, and pathology: I. A
hypothesis and a program for research. Arch Neurol hypothesis and

2 Geschwind N, Galaburda AM. Cerebral lateralization: biological mechanisms, associations, and pathology: II. A hypothesis and a program for research. Arch Neuro 1985;42:521-52.
3 Geschwind N, Galaburda AM. Cerebral lateralization: biological mechanisms, associations, and pathology: III. A hypothesis and a program for research. Arch Neurol 1985;42:634-54

4 Geschwind N, Levitsky W. Human brain: left-right asymmetries in temporal speech region. Science 1968;161:186-7.

5 Ouden LD, Rijken M, Brand R, Vanhorick PV, Ruys JH. Is it correct to correct? Developmental milestones in 555 'normal' preterm infants compared with term infants. $\mathcal{f}$ Pediatr 1991;118:399-04

6 Tsur VG, Manor O, Shalev RS. Developmental dyscalculia, gender, and the brain. Arch Dis Child 1993;68:510-2.

7 Mehta Z, Newcombe F, Damasio H. A left hemisphere contribution to visuospatial processing. Cortex 1987;23:44761.

8 Mehta Z, Newcombe F. A role for the left hemisphere in spatial processing. Cortex 1991;27:153-67.

9 Hedges LV, Nowell A. Sex differences in mental test scores, variability, and numbers of high scoring individuals. Science 1995;269:41-5.

10 Willerman L, Schultz R, Rutledge JM, Bigler ED. In vivo brain size and intelligence. Intelligence 1991;15:223-8.

11 Sells CJ, Robinson NM, Brown Z, Knopp RH. Long term developmental follow up of infants of diabetic mothers. $\mathcal{F}$ Pediatr 1994;125:S9-17. 